\title{
Interviews on Eunamus
}

Storicamente, 8 (2012).

ISSN: 1825-411X. Art. no. 30. DOI: 10.12977/stor556

Interviews about Eunamus

[[figure caption="logo" width="120px" fancybox="true"]]figures/2012/eunamus_interviews/eunamus_interviews_2012_01.jp 